\title{
Deep-water renewal in a Scottish fjord: temperature, salinity and oxygen isotopes
}

\author{
William E. N. Austin \& Mark E. Inall
}

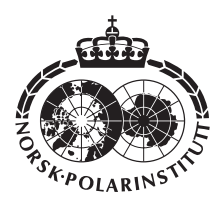

The sea lochs (fjords) of north-west Scotland are located in a region of Europe particularly well situated to monitor changes in westerly air streams. The moisture transported in these air streams has a profound effect on regional precipitation, freshwater run-off and, in turn, sea loch circulation. The gentle slope of the regional salinity: $\delta^{18} \mathrm{O}$ mixing-line, defined as $0.18 \%$ per salinity unit, suggests that the temperature: $\delta^{18} \mathrm{O}$ relationship may be readily resolved in these coastal waters. Deep-water renewal events, both observed and predicted from empirical models, in the bottom-waters of Loch Etive provide an opportunity to assess the temperature, salinity and $\delta^{18} \mathrm{O}$ relationship. Predicted changes in $\delta^{18} \mathrm{O}_{\text {calcite }}$ as a function of changing salinity $(\Delta S)$ and changing temperature $(\Delta \mathrm{T})$ during deep-water renewal events suggest that $>80 \%$ fall above analytical detection limits. The theoretical likelihood of recording such renewal events in the "palaeoclimate" record appears to be promising, but temperature and salinity change during renewal events may have either sign. Scottish fjords, because of the relatively small impact which salinity has on $\delta^{18} \mathrm{O}_{\text {water }}$, may provide useful study sites in palaeoclimate research, particularly where palaeotemperature is the primary record of interest.

W. E. N. Austin, School of Geography and Geosciences, University of St. Andrews, St. Andrews, Fife, Scotland KY16 9AL, UK; M. E. Inall, Scottish Association for Marine Science, Dunstaffnage Marine Laboratory, Oban, Argyll, Scotland PA37 1QA, UK.

The fractionation and resulting ratio changes of the stable oxygen isotopes ${ }^{18} \mathrm{O}$ and ${ }^{16} \mathrm{O}$ provide a powerful tool in our understanding of the global hydrological cycle (e.g. Dansgaard 1964; Craig \& Gordon 1965). In mid-latitude coastal regions, freshwater run-off and ground waters (depleted in ${ }^{18} \mathrm{O}$ ) mix with oceanic (shelf) water (enriched in $\left.{ }^{18} \mathrm{O}\right)$ to define salinity: $\delta^{18} \mathrm{O}_{\text {water }}$ relationships (e.g. Mikalsen \& Sejrup 2000).

An understanding of the quantitative salinity: $\delta^{18} \mathrm{O}$ relationship provides a means of modelling the $\delta^{18} \mathrm{O}$ response in these coastal/fjord waters. If salinity changes, then so too will the $\delta^{18} \mathrm{O}$ of that water. The incorporation of the $\delta^{18} \mathrm{O}_{\text {water }}$ signal into the calcium carbonate skeletal structure of marine organisms $\left(\delta^{18} \mathrm{O}_{\text {calcite }}\right)$ is also temperature dependent (e.g. Urey 1947). The first empirical temperature: $\delta^{18} \mathrm{O}$ relationship was developed by McCrea (1950) and the first "palaeotemperature" equation was published by Epstein et al. (1953). Changes in both salinity and temperature therefore have the potential to be recorded in the palaeoclimate record of marine organisms $\left(\delta^{18} \mathrm{O}_{\text {calcite }}\right)$. It is therefore highly desirable to understand the factors (both spatial and temporal) governing $\delta^{18} \mathrm{O}$ within modern sea loch environments

Scottish fjords are generally deep, semienclosed basins with a shallow sill at the mouth. A tidal variation in sea level is forced at the mouth, and fresh water is input into the interior. In general there may also be variation in baroclinic forcing 


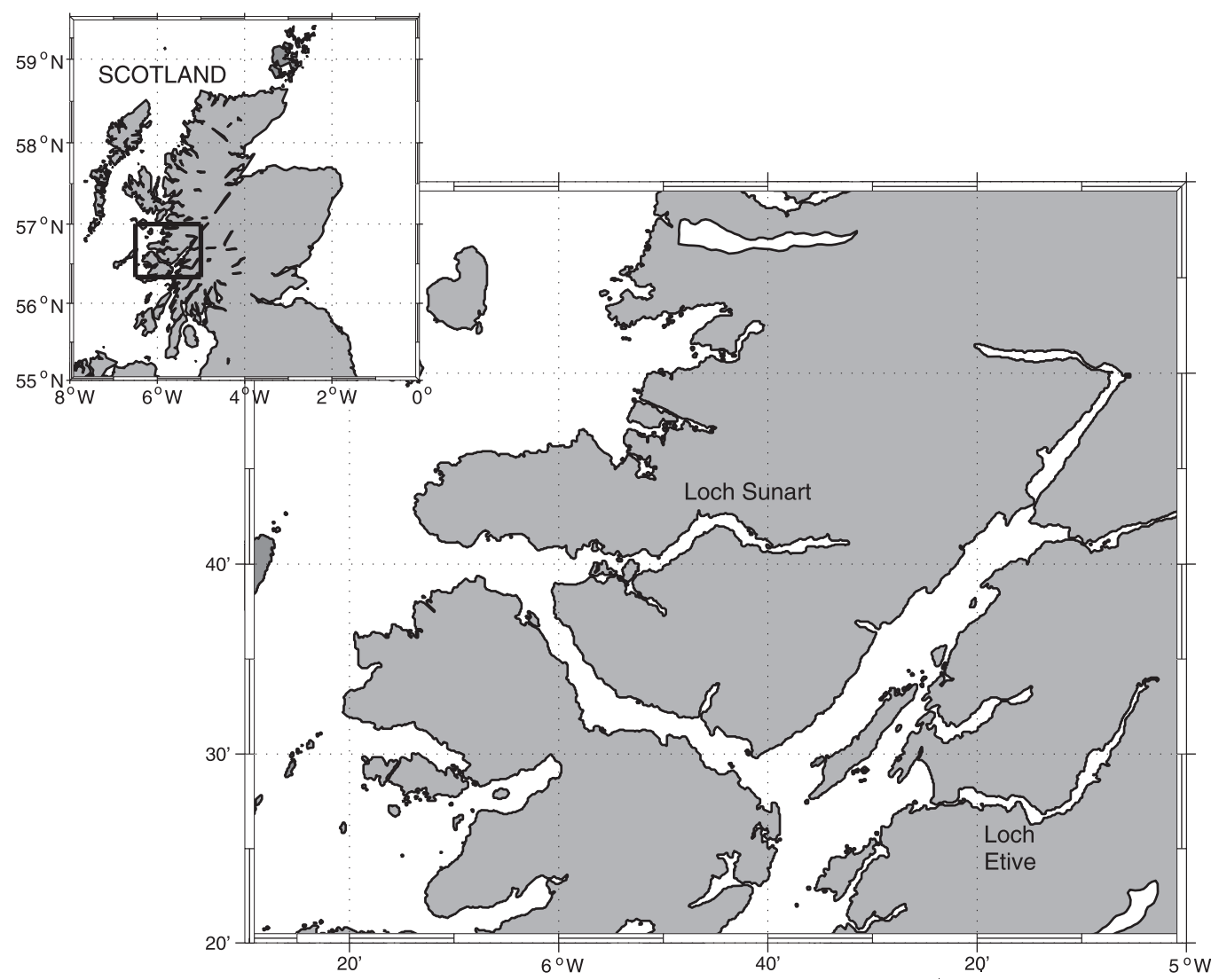

Fig. 1. Location map. Inset shows locations of Loch Etive and Loch Sunart on the Scottish west coast.

from changes in density and stratification at the seaward side of the sill, driven, for example, by upwelling or downwelling along the continental shelf margin. The presence of a shallow sill at the fjord mouth cuts off basin water, lying below a certain level, from direct communication with the continental shelf and the open ocean. As a result the deep-water properties are altered only through local diffusion within the basin, convective overturning within the basin, or when the cross-sill inflow is sufficiently dense to sink into the basin and uplift the bottomwaters.

The most dramatic changes in deep-water properties occur during the last of these three processes, usually referred to as a deep-water renewal event. In shallow-silled fjords with strong tidal currents, deep-water renewals generally occur after a period of low freshwater run-off. Low freshwater run-off may result from either low precipitation (summer) or sub-zero catchment area temperatures (winter). Thus, whilst deep-water renewal events generally result in a sharp increase in the salinity of basin deepwater, the event may be accompanied by a temperature change of either sign, depending on the surface water temperature at the time of renewal. Between renewal events, deep-water density is gradually reduced by diffusive vertical mixing with fresher surface waters. This diffusive mixing, thought to be mediated by the action of internal wave breaking (Inall \& Rippeth 2002), preconditions the deep-water for the next renewal event.

\section{Study area}

Two fjords on the west coast of Scotland have been selected for this study: Loch Sunart and Loch Etive (Fig. 1). 
Loch Sunart is $33 \mathrm{~km}$ long, with an average width of $1.5 \mathrm{~km}$, a maximum depth of $124 \mathrm{~m}$, and consists nominally of six sills and basins (Edwards \& Sharples 1986). The tidal regime in the loch is predominantly semidiurnal, with a range of $4 \mathrm{~m}$ at springs and $1 \mathrm{~m}$ at neaps. The catchment area is approximately $300 \mathrm{~km}^{2}$, with mountainous ground to the north and east, and approximately half the freshwater enters the system in the upper basin. Loch Sunart has one of the smallest freshwater discharge to tidal flow ratios among Scottish lochs (Edwards \& Sharples 1986), probably contributing to the relatively frequent renewal of its bottom-waters (Gillibrand et al. 1995).

Loch Etive, on the other hand, has one of the highest freshwater discharge to tidal flow ratios among Scottish lochs (Edwards \& Sharples 1986). The upper basin of Loch Etive is $16 \mathrm{~km}$ long, with an average width of $1.2 \mathrm{~km}$, and a maximum depth of $145 \mathrm{~m}$. The sill is narrow $(200 \mathrm{~m})$, and shallow (approximately $14 \mathrm{~m}$ ). Tidal forcing is predominantly semi-diurnal, with a neap range of $1.1 \mathrm{~m}$ and a spring range of $1.8 \mathrm{~m}$. Tidal flows in excess of $1.5 \mathrm{~ms}^{-1}$ have been observed over the sill, resulting in rapid loss of tidal energy near the sill, which may in turn reduce the efficacy of diffusive preconditioning. This, combined with the high freshwater input, results in a mean renewal period of 1.3 years (Edwards \& Edelsten 1977). Renewal events, when they do occur, result in rapid deep-water property changes of typically 1 unit in salinity, and warming or cooling of 1 to $2{ }^{\circ} \mathrm{C}$.

\section{Rationale of the study}

The sea lochs (fjords) of north-west Scotland are located in a region of Europe particularly well situated to monitor changes in westerly air streams. Interannual atmospheric circulation changes at this latitude are largely governed by the North Atlantic Oscillation (NAO), a largescale meridional oscillation of atmospheric mass between the subtropical anticyclone near the Azores and the subpolar low pressure system near Iceland (Hurrell 1995). The influence of the NAO on both precipitation and westerlies is well established (e.g. Trigo et al. 2002). Longterm variability in the NAO index, reflecting the dominant mode of atmospheric behaviour in the North Atlantic region, is observed over a range of multi-annual periodicities, most of which have a period of less than 15 years (Appenzeller et al. 1998).

Scottish sea lochs bridge the land-ocean interface, are highly sensitive to freshwater runoff, and therefore provide a potential link between the climate fluctuations associated with westerly air streams and the physical and chemical properties of the bottom-water of fjords. The aim of this study is to establish the regional salinity: $\delta^{18} \mathrm{O}$ relationship and to evaluate the potential of recording deep-water renewal events in the sea loch environment. It is beyond the scope of this paper to address how such events might be recognized and resolved in the palaeo-record.

\section{Methods}

\section{Salinity and $\delta^{18} O_{\text {water }}$}

A total of 22 water samples collected from Loch Sunart during June 1999 are employed to derive a regional salinity: $\delta^{18} \mathrm{O}$ relationship for fjord waters. Salinity measurements were made using a Guildline salinometer, at the School of Ocean Sciences, University of Wales, and are reported with a precision of $+/-0.02$ salinity units. The stable oxygen isotope measurements were made at the Scottish Universities Environmental Research Centre. The $\delta^{18} \mathrm{O}$ measurements are based on 1 $\mathrm{ml}$ volumes, determined via $\mathrm{CO}_{2}$ equilibration with an automated water equilibrator attached to an isotope ratio mass spectrometer. Data are reported with standard deviations of about $+/$ $-0.15 \%$ relative to Vienna standard mean ocean water (VSMOW).

\section{Deep mooring observations}

A standard U-shaped mooring was maintained in the deep basin of upper Loch Etive from 6 April 2000 until 10 July 2001 (position 56 27.37' N, $05^{\circ} 11.17^{\prime} \mathrm{W}$; water depth $145 \mathrm{~m}$ ). At a distance of $1.7 \mathrm{~km}$ landward of the sill, the mooring was located on the central axis and in the deepest part of the upper basin and instrumented with a Seabird T/S sensor and an Aanderaa current meter at $15 \mathrm{~m}$ above the sea floor. Further T/S instruments were positioned throughout the water column. Observations from the T/S sensor located at $15 \mathrm{~m}$ above the sea floor are reported here. Two complete renewal events were observed during the mooring deployment. 


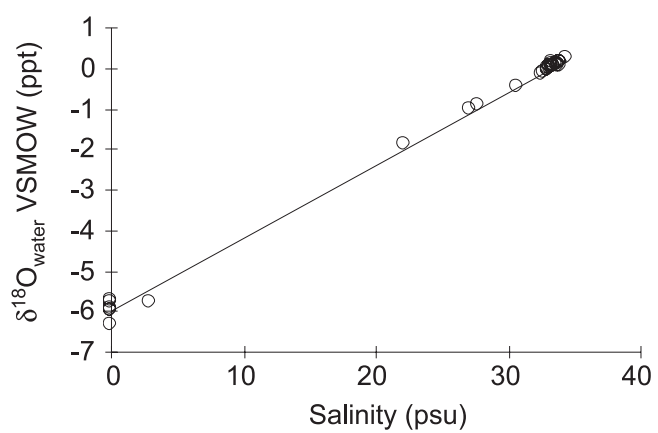

Fig. 2. Salinity: $\delta^{18} \mathrm{O}$ mixing line, Loch Sunart, July 1999 $(\mathrm{n}=22) . \delta^{18} \mathrm{O}_{\text {water }}=0.18 * \mathrm{~S}-6.0\left(\mathrm{R}^{2}=0.998\right)$.

\section{Results and discussion}

\section{Regional salinity: $\delta^{18} O_{\text {water }}$ relationship}

The regional salinity: $\delta^{18} \mathrm{O}_{\text {water }}$ mixing-line for Scottish west coast waters, ranging from fresh water to fully marine water (Fig. 2), is defined by the following relationship:

$$
\delta^{18} \mathrm{O}_{\text {water }}=0.18 * \mathrm{~S}-6.0
$$

At zero salinity $(\mathrm{S}=0)$, the predicted $\delta^{18} \mathrm{O}_{\text {water }}$ of freshwater entering the coastal environment is $-6.0 \%$. Observed values, collected from the freshwater tributaries entering Loch Sunart in July 1999, range from -5.76 to $-6.32 \%$. These observed and predicted values are consistent with the weighted annual $\delta^{18} \mathrm{O}_{\text {water }}$ in precipitation from this region of north-west Europe (Fig. 3), which lies within the range -5 to $-8 \%$ (IAEA 2001). The fairly broad range of the latter reflects the fact that data have been contoured, based on the interpolation of a fairly limited amount of Global Network for Isotopes in Precipitation (GNIP) station data, spanning a wide geographical region (J. Birks, pers. comm. 2002).

The extent to which seasonal precipitation differences in $\delta^{18} \mathrm{O}_{\text {water }}$, dampened as they are in stream waters (e.g. Soulsby et al. 2000), influence the slope of the coastal mixing lines is largely unknown. Periods of spring snow melt, for example, may release large volumes of isotopically depleted water into the coastal environment and may, for a short time, increase the slope of the salinity: $\delta^{18} \mathrm{O}_{\text {water }}$ mixing-line. An extended regional study of north-west European to Arctic salinity: $\delta^{18} \mathrm{O}_{\text {water }}$ mixing-lines is currently underway (Mikalsen \& Austin unpubl. data). In the high latitudes, for example, the impact of sea ice formation and melting may significantly alter the seasonal evolution of salinity: $\delta^{18} \mathrm{O}_{\text {water }}$ relationships (e.g. Strain \& Tan 1993).

Deep-water renewal: temperature and salinity changes

Prior to the Loch Etive deep-water renewal event of May 2000 (Fig. 4) a slow, gradual decline in bottom-water salinity of $<0.1$ over a period of weeks is observed, a signature of vertical diffusive mixing between deep-water and fresher intermediate water. On 9 May, between 10:08 and 11:22 on a flooding spring tide, the salinity dropped by 0.39 and the temperature by $1.63^{\circ} \mathrm{C}$. The mean current speed rose from 2.4 $\mathrm{cm} / \mathrm{s}^{-1}$ during the 24.84 hours before the event to $10.1 \mathrm{~cm} / \mathrm{s}^{-1}$ over the same period after the event. CTD casts made on 25 April and 5 June revealed an increase in dissolved oxygen from $0.9 \mathrm{mg} / \mathrm{l}^{-1}$ to $9.5 \mathrm{mg} / \mathrm{l}^{-1}$ at $15 \mathrm{~m}$ above the sea floor. All these pieces of evidence demonstrate the effect of a full deep-water renewal event on the deep basin water of upper Loch Etive. The dense coastal water, presented at the sill by the spring tide, floods over the sill, runs down the inner face of the sill as a density current, and displaces upward the old water previously residing in the depths of the basin.

\section{Predicting $\delta^{18} O_{\text {water }}$ and $\delta^{18} O_{\text {calcite }}$}

Regional salinity: $\delta^{18} \mathrm{O}_{\text {water }}$ mixing-lines provide a means to predict the $\delta^{18} \mathrm{O}_{\text {water }}$ composition of coastal water from observations of salinity. The Loch Etive deep-water renewal event of May 2000 (Fig. 4) is characterized by a sudden decline in bottom-water salinity of nearly 0.5 . Applying Eq. (1) to estimate $\delta^{18} \mathrm{O}_{\text {water }}$, a corresponding and equivalent shift of about $0.09 \%$ is obtained. The effect of salinity associated with the renewal event of May 2000 is therefore less than the analytical precision of our measurements $(+/-0.15 \%$ ) $)$.

In this study, the temperature: $\delta^{18} \mathrm{O}$ relationship adopted comes from Bemis et al. (1998):

$$
\mathrm{T}\left({ }^{\circ} \mathrm{C}\right)=16.5-4.8\left(\delta^{18} \mathrm{O}_{\text {calcite }}-\delta^{18} \mathrm{O}_{\text {water }}\right)
$$

To explore the impact of temperature on "equilibrium" calcite, the $\delta^{18} \mathrm{O}_{\text {water }}$ correction of $-0.27 \%$ (Hut 1987) is employed to convert from the VSMOW to the Vienna Pee Dee belemnite 
Fig. 3. North-western European mean annual $\delta^{18} \mathrm{O} \%$ (VSMOW) in precipitation (modified from IAEA 2001).
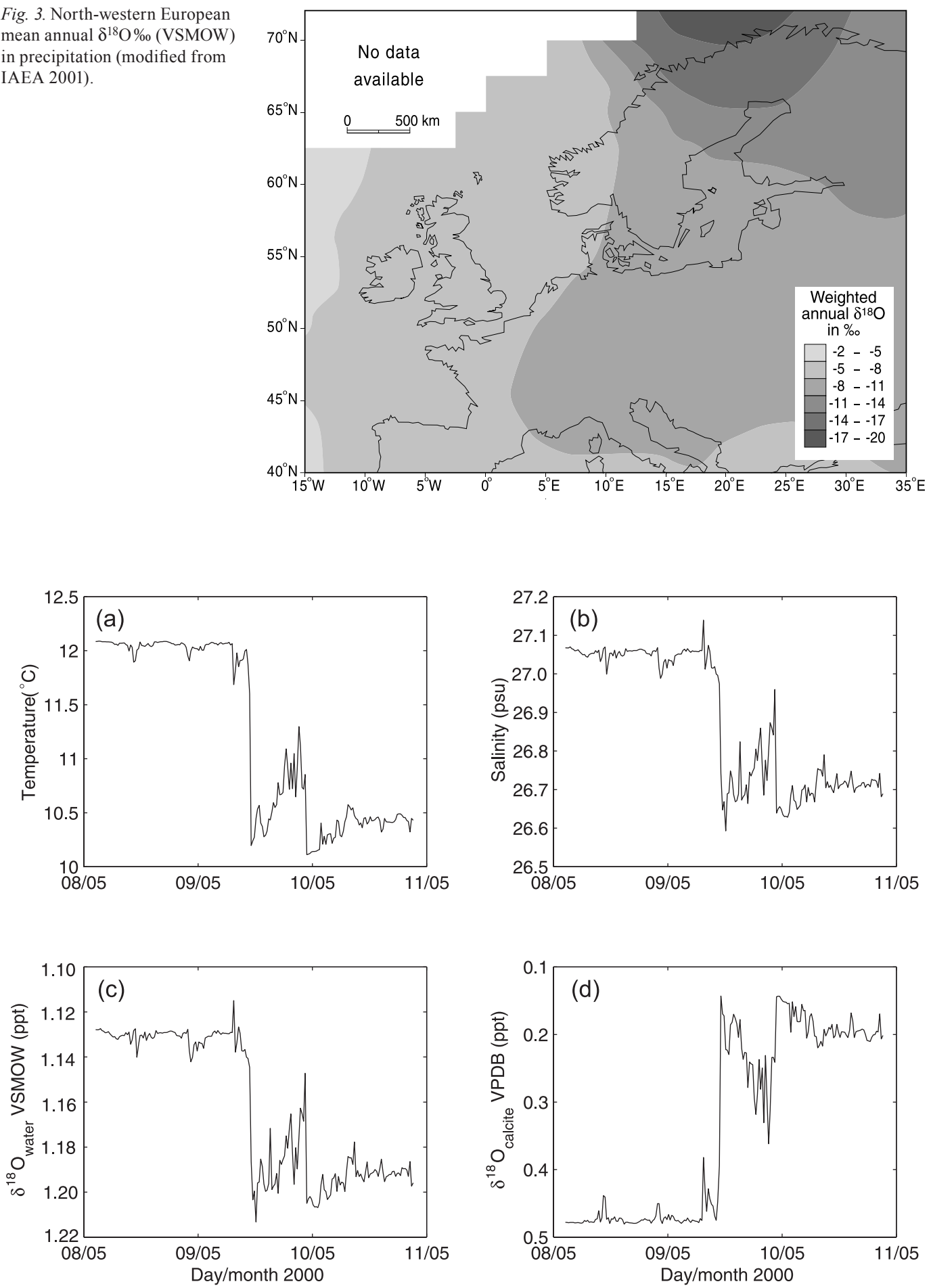

Fig. 4. Mooring data, Deep Basin, Loch Etive (May 2000): (a) temperature $\left({ }^{\circ} \mathrm{C}\right)$; (b) salinity; (c) $\delta^{18} \mathrm{O}_{\text {water }}(\%$, VSMOW); (d) $\delta^{18} \mathrm{O}_{\text {calcite }}(\%$, VPDB). 


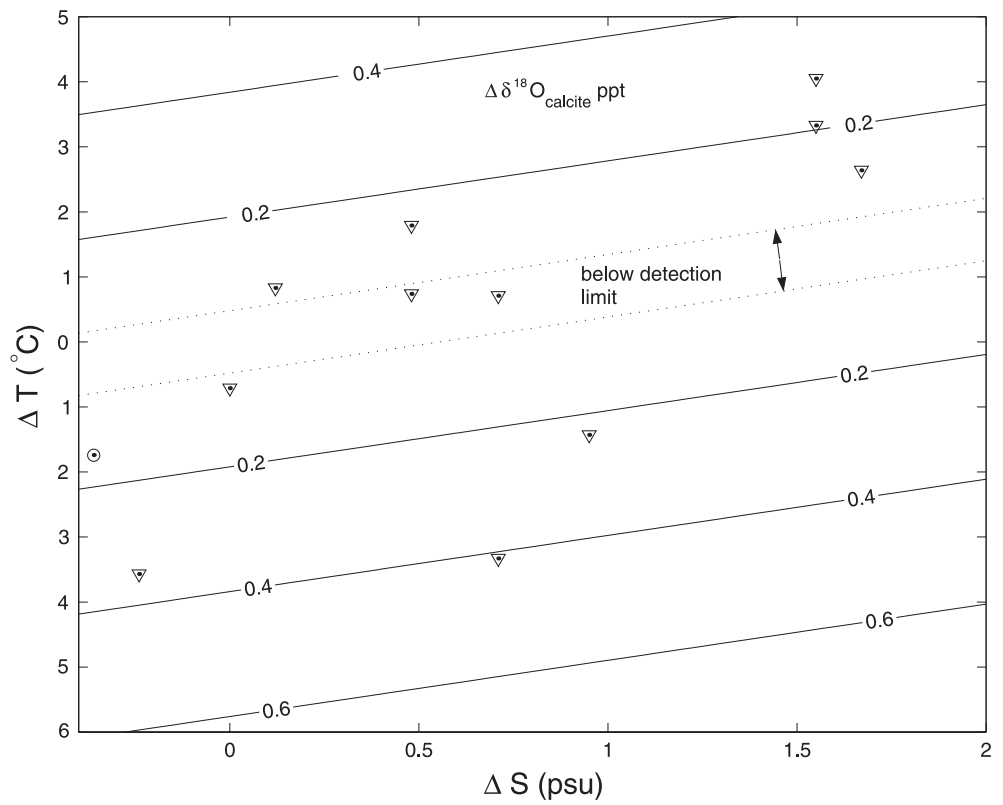

Fig. 5. Temperature and salinity changes of the bottom-waters of Loch Etive from before to after renewal events. Triangles indicate modelled renewal events of Edwards \& Edelsten (1977); the circle indicates the observed event reported here. Contours are of predicted changes in $\delta^{18} \mathrm{O}_{\text {calcite }}$, produced as a result of temperature and salinity changes; the area between the broken lines is below the detection limits of the measuring technique.
(VPDB) scale:

$$
\delta^{18} \mathrm{O}_{\text {water(VPDB })}=\delta^{18} \mathrm{O}_{\text {water(VSMOW })}-0.27
$$

From Eqs. (1), (2) and (3), it is possible to derive an estimate of the theoretical "equilibrium" calcite $\left({ }^{18} \mathrm{O}_{\text {calcite }}\right)$ from any given observation of salinity and temperature. Using the deep mooring data from Loch Etive, we calculate a theoretical $\delta^{18} \mathrm{O}$ change of approximately $0.3 \%$ associated with the deep-water renewal event of May 2000 (Fig. 4). In terms of the potential impact on "equilibrium" $\delta^{18} \mathrm{O}_{\text {calcite }}$, temperature is the most significant feature of this renewal event. Analytical precision of the $\delta^{18} \mathrm{O}$ analyses of marine carbonates is often reported as $+/$ $-0.05 \%$ relative to the VPDB standard (e.g. Bemis et al. 1998) and it should, theoretically, be possible to detect such events if they are preserved and resolved in the palaeoclimate record of Scottish sea lochs.

\section{Historic renewal events in Loch Etive}

Twelve renewal events for the upper basin of Loch Etive have been examined to determine the probability of event detection by $\delta^{18} \mathrm{O}_{\text {calcite }}$ measurement. Eleven of these events come from the empirical model predictions of Edwards \& Edelsten (1977), the twelfth is a deep-water renewal event recorded in May 2000 (Fig. 4). All events are described in terms of the change in salinity and temperature experienced in the bottom of the deep basin before and after renewal (Fig. 5). Equations (1) and (2) are differentiated with respect to $\mathrm{S}$ and $\mathrm{T}$, respectively, and combined and rearranged to give an expression for the change in $\delta^{18} \mathrm{O}_{\text {calcite }}$ as a function of a change in salinity $(\Delta \mathrm{S})$ and a change in temperature $(\Delta \mathrm{T})$.

Calculating changes in $\delta^{18} \mathrm{O}_{\text {calcite }}$ over a typical range of $\Delta \mathrm{S}$ and $\Delta \mathrm{T}$, and noting that measurement precision of the $\delta^{18} \mathrm{O}_{\text {calcite }}$ is $+/-0.05 \%$, allows us to predict which of the historical overturn events can be detected. From the twelve deep-water renewal events considered, only two fall below the detection limit, while a further two lie close to the limit (Fig. 5).

\section{Conclusions}

The data presented in this paper provide the first regional salinity: $\delta^{18} \mathrm{O}_{\text {water }}$ mixing-lines for the coastal waters of north-western Scotland. Deepwater mooring data from Loch Etive provide rare insight into the timing and magnitute of a deep-water renewal event. As anticipated, the slope of the mixing-line (0.18) is less than similar 
relationships defined for the North Sea (0.25; Israelson \& Buchardt 1991) and the Sognefjord, western Norway (0.31; Mikalsen \& Sejrup 2001). Such spatial gradients in the salinity: $\delta^{18} \mathrm{O}_{\text {water }}$ mixing-lines, from the coastal regions of north-western Europe to the Arctic, are to be expected because of the regional pattern of $\delta^{18} \mathrm{O}_{\text {water }}$ in precipitation (Fig. 3; Mikalsen \& Austin, unpubl. data). Scottish fjords, because of the relatively small impact which salinity has on $\delta^{18} \mathrm{O}_{\text {water }}$, may provide useful study sites in palaeoclimate research, particularly where palaeotemperature is the primary record of interest. Sclerochronological and stable isotopic analyses of banded mollusc shells, such as the long-lived species Arctica islandica, may provide a means of detecting such events in the recent geological record.

Acknowledgements.-WENA thanks Anne Hamerstein (School of Ocean Sciences [SOS], University of Wales) for help with salinity measurements, Hilary Kennedy (SOS), Andrew Tait and Tony Fallick (Scottish Universities Environmental Research Centre, East Kilbride) - all for help with stable isotope measurements. Jack Jarvis and Richard Bates provided field assistance. Financial support from the Royal Society, Carnegie Trust, and EU Framework V (HOLSMEER) are gratefully acknowledged. WENA also thanks Gaute Mikalsen, Phil Gillibrand, Tony Fallick and Jean Birks for their helpful comments and advice. MEI thanks Colin Griffiths (DML) for mooring design, deployment and recovery, instrument calibration and data processing.

\section{References}

Bemis, B. E., Spero, H. J., Bijma, J. \& Lee, D. W. 1998:Reevaluation of the oxygen isotopic composition of planktonic foraminifera: Experimental results and revised paleotemperature equations. Paleoceanography 13, 150-160.

Craig, H. \& Gordon, L. I. 1965: Deuterium and oxygen 18 variations in the oceans and the marine atmosphere. In E. Tongiorgi (ed.): Stable isotopes in oceanographic studies and paleotemperatures. Pp. 9-130. Pisa: Laboratory of Nuclear Geology, National Research Council.

Dansgaard, W. 1964: Stable isotopes in precipitation. Tellus 16, 436-468.

Edwards, A. \& Edelsten, D. J. 1977: Deep water renewal of Loch Etive: a three basin Scottish fjord. Estuar. Coast. Mar. Sci. 5, 575-595.

Edwards, A. \& Sharples, F. 1986: Scottish sea lochs: a catalogue. Spec. Publ. 134. Oban, Scotland: Scottish Association of Marine Science.

Epstein, S., Buchsbaum, R., Lowenstam, H. A. \& Urey, H. C. 1953: Revised carbonate-water isotopic temperature scale. Geol. Soc. Amer. Bull. 64, 1315-1325.

Gillibrand, P. A., Turrell, W. R. \& Elliott, A. J. 1995: Deepwater renewal in the upper basin of Loch Sunart, a Scottish fjord. J. Phys. Oceanogr. 25, 1488-1503.

Hurrell, J. W. 1995: Decadal trends in the North Atlantic Oscillation-regional temperature and precipitation. Science 269, 676-679.

Hut, G. 1987: Consultants group meeting on stable isotope reference samples for geochemical and hydrological investigations, 16-18 September 1985, Vienna. Report to Director General, International Atomic Energy Agency.

IAEA (International Atomic Energy Agency) 2001: GNIP maps and animations. Vienna: IAEA. Accessible at http: //isohis.iaea.org.

Inall, M. E. \& Rippeth, T. P. 2002: Dissipation of tidal energy and associated mixing in a wide fjord. Environ. Fluid Mech. 12, 219-263.

Israelson, C. \& Buchardt, B. 1991: The isotopic composition of oxygen and carbon in some fossil and recent bivalve shells from East Greenland. LUNDQUA Rep. 33, 117-123. Lund University.

McCrea, J. M. 1950: On the isotopic chemistry of carbonates and a paeotemperature scale. J. Chem. Phys. 18, 849-857.

Mikalsen, G. \& Sejrup, H. P. 2000: Oxygen isotope composition of fjord and river water in the Sognefjorden drainage area, western Norway: implications for palaeoclimate studies. Estuar. Coast. Shelf Sci. 50, 441-448.

Soulsby, C., Malcolm, R., Helliwell, R., Ferrier, R. C. \& Jenkins, A. 2000: Isotope hydrology of the Allt a'Mharcaidh catchment, Cairngorms, Scotland: implications for hydrological pathways and residence times. Hydrol. Process. 14 , 747-762.

Strain, P. M. \& Tan, F. C. 1993: Seasonal evolution of oxygen isotope-salinity relationships in high-latitude surface waters. J. Geophys. Res. 98(C8), 14589-14598.

Urey, H. C. 1947: The thermodynamic properties of isotopic substances. J. Chem. Soc. 1947, 562-581. 